\title{
Molecular serotyping of Salmonella strains isolated from retail chicken meats by in silico derived multiplex PCR, determination of ESBL, and colistin resistance genes $m c r-1$ to -5
}

\author{
Mehmet C. Adiguzel ${ }^{1 *}$, Seyda Cengiz ${ }^{1}$, and Alper Baran ${ }^{2}$ \\ ${ }^{1}$ Department of Microbiology, Faculty of Veterinary Medicine, Atatürk University, Erzurum, Turkey \\ ${ }^{2}$ Department of Food Quality Control and Analysis, Erzurum Vocational School, Atatürk University, \\ Erzurum, Turkey
}

\begin{abstract}
ADIGUZEL, M. C., S. CENGIZ, A. BARAN: Molecular serotyping of Salmonella strains isolated from retail chicken meats by in silico derived multiplex PCR, determination of ESBL, and colistin resistance genes $m c r-1$ to -5 . Vet. arhiv 91, 179-187, 2021.
\end{abstract}

\section{ABSTRACT}

Salmonella spp. are zoonotic pathogenic agents that cause important infections in humans and animals. They are the most common foodborne pathogens after Campylobacter spp. worldwide. The aim of this study was to determine the phenotypic and genotypic extended-spectrum $\beta$-lactamase (ESBL) and colistin resistance of 67 Salmonella spp. isolated from retail chicken meats between May and December 2016, and stored in the culture collection of Ataturk University, Faculty of Veterinary Medicine, Department of Microbiology. The isolates were serotyped using multiplex polymerase chain reaction (mPCR). The serovar distribution of strains was $74.6 \% S$. Infantis, $16.4 \% S$. Enteritidis, $3.0 \% S$. Arizonae, $3.0 \% S$. Dublin, $1.5 \% S$. Gallinarum and 1.5\% S. Indica. Of the 67 strains, $20(29.9 \%)$ were ESBLpositive. The main types of $\beta$-lactamase identified were $b l a_{\mathrm{CTX}-\mathrm{M}-1}, b l a_{\mathrm{CTX}-\mathrm{M}-8-25}, b l a_{\mathrm{SHV}}$ and $b l a_{\mathrm{TEM}}$. Four isolates were found to be phenotypically colistin-resistant. These isolates did not carry mobilised colistin resistance ( $\mathrm{mcr}$ ) genes 1 to 5. In this study, both genotypically ESBL-producing and phenotypically colistin-resistant Salmonella strains were found. We revealed that ESBL-producing Salmonella strains have dramatically increased over the years, especially when compared with previously reported chicken meat Salmonella strains in Turkey. The increase in Salmonella strains, particularly ESBL producers and the colistin resistant, is of great concern for selected antimicrobial therapy in human infections. Hence, epidemiological information and monitoring systems are extremely important in controlling Salmonella infections in public health services.

Key words: colistin; ESBL; Retail chicken meat; Salmonella spp.; serotyping

\section{Introduction}

Salmonella spp. are zoonotic pathogenic agents that cause serious infections in humans and animals (NIDAULLAH et al., 2016; SAHAN et al., 2016; BARAN et al., 2019). The global increase in the consumption of poultry products has led to the need for the production of food of higher quality and uncontaminated by foodborne pathogens. According to European Union data, a total of 91,662 cases of human Salmonella were reported in 2018. Salmonellosis is the second most common zoonotic

\footnotetext{
*Corresponding author:

Atatürk University, Faculty of Veterinary Medicine, Department of Microbiology, 25240, Erzurum, Turkey, Phone: +90 553 451 9306 ; E-mail: mcemal.adiguzel@atauni.edu.tr
} 
disease after campylobacteriosis. It is also known that Salmonella spp. are mostly isolated from poultry and egg-containing products, which are therefore among the main sources of salmonellosis. Due to the high prevalence of Salmonella species in poultry, control programs are applied to poultry in Turkey, as well as in many other countries (SAHAN et al., 2016; EFSA and ECDC, 2018).

Salmonella spp. is known to include more than 2,500 serovars. Salmonella enterica subsp. enterica includes approximately 1,500 serovars, many of which can infect humans and animals. The identification of these serovars is based on the conventional detection of flagellar (H-antigens) and surface antigens (O-antigens). The KauffmannWhite scheme has long been used as the standard serotyping method. This serotyping process is expensive, labour-intensive and time-consuming, often requiring three or more days for experienced staff to produce results (LEADER et al., 2009; BORAH et al., 2017). Consequently, polymerase chain reaction (PCR)-based serotyping methods, which are easier, faster and time-saving, have recently been used by several researchers (ARRACH et al., 2008; LEVY et al., 2008; BORAH et al., 2017).

Multidrug-resistant Salmonella spp. have been detected after excessive use of antibiotics and feed additives in animal breeding (BASARAN KAHRAMAN et al., 2016). Some Salmonella serovars are more prone to developing multidrug resistance (MDR) than others, and thus infect humans via the food chain. The success rate of treatment decreases in MDR bacterial infections (VAN DUIJKEREN et al., 2003; ATA et al., 2015; KIRKAN et al., 2017). The wide spread of Gramnegative bacteria, such as extended-spectrum $\beta$-lactamase (ESBL)-producing bacteria, causes serious infections worldwide. ESBL-producing bacteria usually acquire resistance to penicillin, cephalosporin and aztreonam. Most multidrugresistant ESBL-producing bacteria are isolated from food-producing animals (LYNCH et al., 2013). Between 2003 and 2007, Salmonella strains of ESBL-producing $b l a_{\text {CTX-M-1 }}, b l a_{\text {СТХ-M-15 }}, b l a_{\text {TEM20, }}$, $b l a_{\text {TEM-52 }}$ genes were recovered from chicken in Germany (RODRIGUEZ et al., 2009). In China,
Salmonella strains from retail chickens harbored ESBL genes $b l a_{\mathrm{CTX}-\mathrm{M}}, \quad b l a_{\mathrm{CMY}}, b l a_{\mathrm{OXA}-1}, b l a_{\mathrm{TEM}}$ between 2007 and 2012 (QIAO et al., 2018). In the USA, S. Infantis was found harbouring the bla ${ }_{\text {СТХ-M-65 }}$ ESBL gene in retail chicken meat in 2014 (BROWN et al., 2018), and ESBL-positive Salmonella strains harboring the $b l a_{\text {СТХ-М-2 }}, b l a_{\text {СТХ-M-8}}, b l a_{\text {СMY-2 }}$ genes from chicken and turkey meat were identified in Brazil between 2008 and 2015 (MOURA et al., 2018). In Turkey, whereas ARSLAN and EYI (2010) detected negative results in chicken meat Salmonella strains in 2010, and ATA et al., (2015) and BABACAN and KARADENIZ (2019) reported ESBL-producing Salmonella strains.

ESBL-producing Salmonella strains may be also resistant to colistin, which has increased interest in antimicrobial resistance. Plasmidmediated mobilised colistin resistance ( $\mathrm{mcr}$ ) genes pose a threat to public health, as they can be transmitted through horizontal gene transfer, and have the potential to spread globally. Therefore, a gene reference that can be used to screen for plasmid-mediated colistin resistance is essential to developing effective control strategies (CARROLL et al., 2019). The aim of this study was to serotype Salmonella spp., previously isolated from retail chicken meats, using multiplex PCR (mPCR), and to identify ESBL-producing and colistin-resistant serovars phenotypically and genotypically.

\section{Materials and methods}

Isolates. This study used 67 Salmonella spp. strains that had been isolated from retail chicken meats between May and December 2016 in our previous study (BARAN et al., 2019) and stored in the culture collection of Ataturk University, Faculty of Veterinary Medicine, Department of Microbiology. The isolates, stored at $-80{ }^{\circ} \mathrm{C}$, were collected on a loop, spread on a Mueller-Hinton Agar (MHA) surface and incubated at $37{ }^{\circ} \mathrm{C}$ for 24 hours.

Multiplex PCR-based serotyping. Multiplex PCR conditions and primers for the serotyping of isolates were used as described previously (BORAH et al., 2017). In brief, to extract genomic DNA, a loopful of bacterial colonies harvested from agar plates was suspended in $0.5 \mathrm{ml}$ sterile water, heated 
at $95{ }^{\circ} \mathrm{C}$ for $10 \mathrm{~min}$ and centrifuged at 5,000 rpm for $5 \mathrm{~min}$ at $4{ }^{\circ} \mathrm{C}$. Four primary master mixes (10x) containing $4 \mu \mathrm{M}$ of each primer were then prepared. Each PCR amplification was performed in a volume of $25 \mu \mathrm{L}$ containing $18.5 \mu \mathrm{L}$ distilled water, 2.5 $\mu \mathrm{L}$ 10x PCR buffer, $1.0 \mu \mathrm{L}$ template DNA, $2.5 \mu \mathrm{L}$ primer master mix and $0.5 \mu \mathrm{L}$ Taq DNA polymerase (Qiagen Inc., Germantown, MD, USA). The PCR conditions were $94^{\circ} \mathrm{C}$ for $3 \mathrm{~min}, 30$ cycles of $94^{\circ} \mathrm{C}$ for $15 \mathrm{sec}, 50{ }^{\circ} \mathrm{C}$ for $30 \mathrm{sec}, 72{ }^{\circ} \mathrm{C}$ for $25 \mathrm{sec}$, and $72{ }^{\circ} \mathrm{C}$ for $5 \mathrm{~min}$. The PCR products were separated by $2 \%$ agarose gel electrophoresis. The results were recorded manually according to the expected amplicon size. Salmonella enterica subsp. enterica serovar Typhimurium (ATCC 14028) was used as a positive control.

Antimicrobial susceptibility test. Detection of ESBL-producing Salmonella spp. was determined by the Kirby-Bauer disc diffusion method, using commercial discs (Himedia, Bombay, India) on Mueller-Hinton Agar (MHA), according to the Clinical Laboratory Standards Institute (CLSI, 2017). The antimicrobial discs contained aztreonam $(30 \mu \mathrm{g})$, ceftriaxone $(30 \mu \mathrm{g})$, cefepime $(30 \mu \mathrm{g})$, cefpodoxime $(10 \mu \mathrm{g})$, cefoxitin $(30 \mu \mathrm{g})$, ceftazidime $(30 \mu \mathrm{g})$ and cefotaxime $(30 \mu \mathrm{g})$. The confirmatory test was determined by the double-disc synergy test using cefotaxime $(30 \mu \mathrm{g})$ and ceftazidime $(30 \mu \mathrm{g})$, and in a combination of ceftazidime-clavulanic acid $(30 / 10 \mu \mathrm{g})$ and cefotaxime-clavulanic acid $(30 / 10 \mu \mathrm{g})$, as recommended by the CLSI (2017). After 16-18 hours of incubation at $35^{\circ} \mathrm{C}, \mathrm{a} \geq 5 \mathrm{~mm}$ increase in the zone diameter of the ceftazidimeclavulanic acid disc and the ceftazidime disc alone, and/or a $\geq 5 \mathrm{~mm}$ increase in the zone diameter of the cefotaxime-clavulanic acid disc and the cefotaxime disc alone were considered as ESBL-producing Salmonella strains.

Detection of colistin resistance. The evaluation of the isolates' phenotypic antimicrobial resistance to colistin was performed using the broth microdilution method (EUCAST, 2017). Cationadjusted Mueller-Hinton broth (Oxoid, Hampshire, UK) was used in order to determine the minimum inhibitory concentration (MIC). Antibiotics diluted in appropriate concentrations $(128-0.125 \mu \mathrm{g} / \mathrm{mL})$ were distributed to $50 \mu \mathrm{L}$ microplates. A bacterial suspension was prepared at a density of 0.5 McFarland with a $24 \mathrm{~h}$ bacterial culture in tryptic soy broth (TSB), diluted to 1:100 with TSB and distributed to all wells in volumes of $50 \mu \mathrm{L}$. The total amount of liquid in each well was $100 \mu$ l. The last well containing the suspension of media and bacteria was used as a negative control. The microplate was sealed and allowed to incubate for $24 \mathrm{~h}$ at $37{ }^{\circ} \mathrm{C}$. At the end of the incubation, the lowest antimicrobial concentration without bacterial growth was recorded as the MIC value. Isolates were resistant to colistin at $>2 \mu \mathrm{g} / \mathrm{mL}$ (ADIGUZEL et al., 2018; EUCAST, 2019).

Genotypic characterization. Genomic DNA extraction was performed, as previously mentioned, in the mPCR-based serotyping section. The PCR amplifications were performed in a total volume of $15 \mu \mathrm{L}$ solution containing $2 \mu 1$ template DNA, 3 $\mu 11 \times$ PCR buffer, $0.25 \mathrm{mM} \mathrm{MgCl}, 200 \mu \mathrm{M}$ dNTP (each), $10 \mathrm{pmol}$ of each primer and $1.25 \mathrm{U}$ of Taq polymerase (Vivantis Technologies, Selangor Darul Ehsan, Malaysia). To screen for the presence of ESBLs in Salmonella spp. isolates, multiplex PCR analysis was performed for simultaneous detection using $b l a_{\mathrm{TEM}}, b l a_{\mathrm{SHV}}, b l a_{\text {CTX-M-1 }}, b l a_{\text {СTX-M-2 }}$, $b l a_{\text {СТХ-м-8-25, }}$, and bla $a_{\text {СТХ-м-9 }}$ group primers, as previously reported by LE et al., (2015).

Mobilised colistin resistance ( $\mathrm{mcr}$ ) genes 1 to 5 were investigated by mPCR. Each PCR amplification was performed in a volume of $25 \mu \mathrm{l}$ containing $12.5 \mu \mathrm{l}$ of DreamTaq PCR master mix (Thermo Scientific, Grand Island, NY, USA), $5.5 \mu 1$ distilled water, $2.0 \mu \mathrm{l}$ template DNA, $0.5 \mu \mathrm{l}$ of each primer (10 pmol) and $2 \mu \mathrm{l}$ target DNA, following the cycling conditions described previously (REBELO et al., 2018; BOROWIAK et al., 2017; XAVIER et al., 2016).

Statistical analysis. The statistical analysis was performed using SPSS statistics 20 (Statistical Package for the Social Science; SPSS Inc., Chicago, IL, USA). To compare between phenotypical colistin resistance and ESBL resistance genes of the individual Salmonella serovars, Pearson probability value ( $P$ value) was calculated using the Chi-square test. A P-value less than 0.05 was considered statistically significant. 


\section{Results}

To determine the molecular serotyping of Salmonella strains by in silico derived amplification, strains were searched by mPCR. The mPCR results showed that 67 strains were determined to be: $74.6 \% S$. Infantis $(\mathrm{n}=50), 16.4 \% \mathrm{~S}$. Enteritidis $(\mathrm{n}=$ $11), 3.0 \% S$. Arizonae $(\mathrm{n}=2), 3.0 \% S$. Dublin $(\mathrm{n}=$ 2), $1.5 \% S$. Gallinarum $(\mathrm{n}=1)$ and $1.5 \% S$. Indica $(\mathrm{n}=1)$.

All phenotypically resistant isolates were screened for ESBL resistance phenotypically and genotypically. One $S$. Indica, one $S$. Arizonae, three $S$. Enteritidis, and $38 S$. Infantis serovars were negative for phenotypic $\beta$-lactam and colistin resistance. Of the 67 Salmonella strains, 20 (29.9\%) were identified as ESBL-producing (Table 1). $\beta$-lactam resistance coding bla ${ }_{\text {СTХ-M-8-25 }}(\mathrm{n}=19)$ and $b l a_{\text {TEM }}(\mathrm{n}=18)$ were the most predominant $\beta$-lactam genes (Fig. 1). In addition, other $\beta$-lactamase genes $b l a_{\mathrm{CTX}-\mathrm{M}-1}$ and $b l a_{\mathrm{SHV}}$ were detected in one and 12 strains, respectively. Groups bla $a_{\text {СТХ-М-2 }}$ and $b l a_{\text {СТХ-м-9 }}$ were not detected in ESBL-producing Salmonella strains.

The MIC of colistin for 67 Salmonella strains are shown in Table 1. The MIC values ranged from $0.5-16 \mu \mathrm{g} / \mathrm{mL}$. Four Salmonella strains (6\%), that is, $S$. Infantis, $S$. Arizona, $S$. Gallinarum, and $S$. Enteritidis, had phenotypical colistin resistance $(>2 \mu \mathrm{g} / \mathrm{mL}$ ). PCR screening for $m c r-1$ to -5 genes in the four colistin resistant strains showed that none of them harbored $m c r-1$ to -5 genes. Furthermore, phenotypic colistin-resistant serovars were found to be ESBL-negative. The incidences of phenotypic colistin resistance and ESBL resistance genes was significantly different in Salmonella serovars by the Pearson Chi-square test (Table 1).

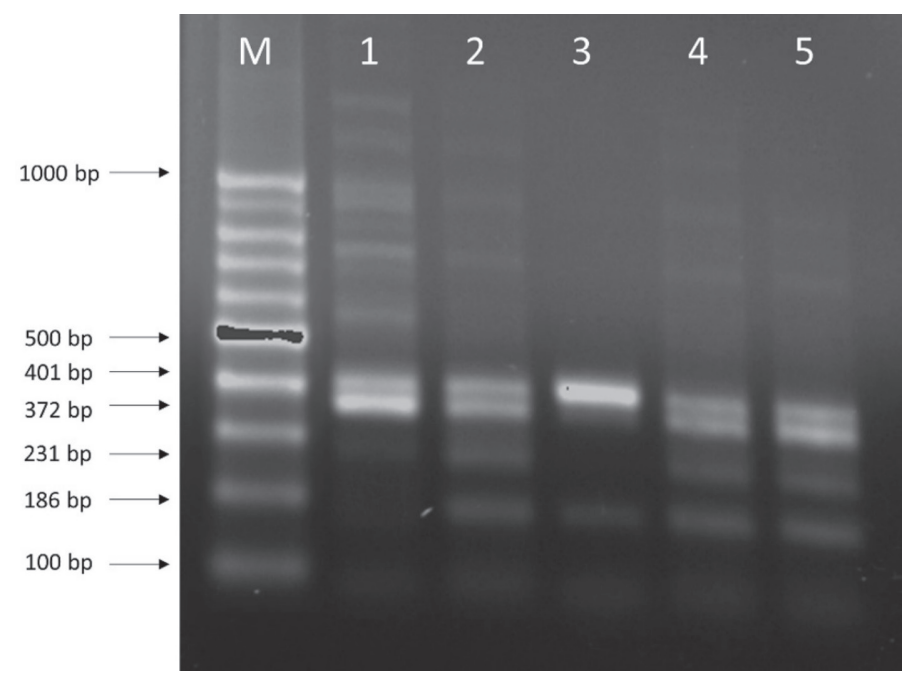

Fig. 1. The result of multiplex polymerase chain reaction of extended-spectrum beta-lactamase producing positive Salmonella strains. M - Marker, 1-5 - Salmonella spp. strains, 186 bp; bla ${ }_{\mathrm{CTX}-\mathrm{M}-8-25}, 231$ bp; bla $a_{\mathrm{SHV}}, 372$ bp; bla ${ }_{\mathrm{TEM}}$, $401 \mathrm{bp} ; 16$ sRNA.

Table 1. Distribution of Salmonella serovar carrying ESBL-produced genes and phenotypical colistin resistance

\begin{tabular}{|c|c|c|c|c|c|c|c|c|}
\hline \multirow[b]{2}{*}{ Salmonella Serovars } & \multicolumn{5}{|c|}{ Colistin resistance range $(\mu \mathrm{g} / \mathrm{mL})$} & \multirow[b]{2}{*}{ ESBL-producing genes } & \multirow{2}{*}{$\begin{array}{c}m c r \\
\text { genes }\end{array}$} & \multirow[b]{2}{*}{$\mathrm{P}$ value } \\
\hline & 0.5 & 1 & 2 & 4 & 16 & & & \\
\hline S. Arizonae $(\mathrm{n}=2)$ & 1 & - & - & 1 & - & - & - & $-*$ \\
\hline S. Dublin $(\mathrm{n}=1)$ & 1 & - & - & - & - & $C T X-M-8 / 25, S H V, T E M$ & - & \multirow{2}{*}{$-*$} \\
\hline$S$. Dublin $(\mathrm{n}=1)$ & 1 & - & - & - & - & $C T X-M-8 / 25, T E M$ & - & \\
\hline
\end{tabular}

*The Chi-square test was not performed because of expected cell less than one 
Table 1. Distribution of Salmonella serovar carrying ESBL-produced genes and phenotypical colistin resistance (continued)

\begin{tabular}{|c|c|c|c|c|c|c|c|c|}
\hline \multirow[b]{2}{*}{ Salmonella Serovars } & \multicolumn{5}{|c|}{ Colistin resistance range $(\mu \mathrm{g} / \mathrm{mL})$} & \multirow[b]{2}{*}{ ESBL-producing genes } & \multirow{2}{*}{$\begin{array}{c}m c r \\
\text { genes }\end{array}$} & \multirow[b]{2}{*}{$P$ value } \\
\hline & 0.5 & 1 & 2 & 4 & 16 & & & \\
\hline$S$. Enteritidis $(\mathrm{n}=5)$ & 4 & 1 & - & - & - & $C T X-M-8-25, S H V, T E M$ & - & \multirow{3}{*}{0.026691} \\
\hline$S$. Enteritidis $(\mathrm{n}=2)$ & 2 & - & - & - & - & $C T X-M-8-25, T E M$ & - & \\
\hline$S$. Enteritidis $(\mathrm{n}=4)$ & 2 & - & 1 & 1 & - & - & - & \\
\hline S. Gallinarum $(\mathrm{n}=1)$ & - & - & - & - & 1 & - & - & $-*$ \\
\hline$S$. Indica $(\mathrm{n}=1)$ & 1 & - & - & - & - & - & - & $-*$ \\
\hline$S$. Infantis $(\mathrm{n}=8)$ & 8 & - & - & - & - & $C T X-M-8-25, S H V, T E M$ & - & \multirow{4}{*}{$<0.00001$} \\
\hline$S$. Infantis $(\mathrm{n}=2)$ & 2 & - & - & - & - & $C T X-M-8-25, S H V$ & - & \\
\hline$S$. Infantis $(\mathrm{n}=1)$ & 1 & - & - & - & - & $C T X-M-1, T E M$ & - & \\
\hline$S$. Infantis $(\mathrm{n}=39)$ & 36 & 1 & 1 & 1 & - & - & - & \\
\hline
\end{tabular}

*The Chi-square test was not performed because of expected cell less than one

\section{Discussion}

Poultry asymptomatically carries Salmonella spp. in the gastrointestinal tract. Cross-contamination commonly occurs during slaughtering. Once contamination occurs in the slaughtering line, its adverse effects are spread throughout the entire process. The absence of separate chilling conditions after the slaughter process promotes the growth of Salmonella spp. in chicken meat. Inadequate hygiene rules in slaughterhouses and careless workers are additional factors that facilitate the spread of Salmonella strains. The antimicrobial resistance of Salmonella serovars in retail chicken meat in Turkey is vitally important because of the potential risk of infections in humans. Therefore, continuous monitoring of antimicrobial-resistant strains is necessary.

Advances in genomic sequence analysis have led to the emergence of alternative methods, such as PCR, pulsed-field gel electrophoresis (PFGE), multilocus sequence typing (MLST) and matrixassisted laser desorption/ionisation-time-of-flight mass spectrometry (MALDI-TOF MS), for the identification of Salmonella serovars. One of these methods is the in silico derived multiplex PCR amplification method, which allows typing by comparing multiplex PCR-based genome typing (MPGT) codes obtained from different mPCR combinations with predetermined serovars (BORAH et al., 2017). In this study, Salmonella serotypes were determined using quadruplex mPCR according to previously confirmed MPGT codes.

Salmonella Typhimurium and Salmonella Enteritidis have previously been reported as the most commonly isolated serovars from chicken meat (WAJID et al., 2019a; YANG et al., 2010). This study found that $S$. Infantis and $S$. Enteritidis serovars were the most common. Other studies have found $S$. Saintpaul, $S$. Brancaster, $S$. Albany, and $S$. Stanley in Singapore (ZWE et al., 2018), $S$. Corvallis and $S$. Albany in Vietnam (NGUYEN et al., 2016), S. Enteritidis in China and Egypt (ABDELGHANY et al., 2015; LI et al., 2017), and $S$. Infantis and $S$. Enteritidis in Turkey (SAHAN et al., 2016). The distribution of serovars obviously varies depending on geographical region.

The widespread, excessive and long-term use of antimicrobial agents can lead to resistance in many bacteria, including Salmonella. In addition, the increase in the prevalence of multidrugresistant Salmonella strains has become a worrying phenomenon both in Turkey and globally (ABBASOGLU and AKCELIK, 2011; 
AVSAROGLU et al., 2007; NÓGRÁDY et al., 2012). Beta-lactam antibiotics are especially preferred for the treatment of invasive Salmonella infections. In contrast to our findings, low levels of ESBL-producing Salmonella strains have previously been reported in Turkey (ATA et al., 2015; BABACAN and KARADENIZ, 2019). This study shows that ESBL-producing resistance genes are carried horizontally and have increased sharply over the years.

Many countries have experienced an increase in $S$. Infantis isolates in poultry and cases of human salmonellosis (ABBASOGLU and AKCELIK, 2011; NÓGRÁDY et al., 2012; WAJID et al., 2019b), mainly sourced from chicken farms and chicken meat (EFSA and ECDC, 2018). NÓGRÁDY et al., (2012) revealed the genetically close association of $S$. Infantis isolated from human and broilers. ESBLproducing genes such as bla $\mathrm{CTXM-M}_{\text {, }}, \mathrm{bla}_{C T X-M-8-25}$, bla $_{T E M}$, and $b^{\prime} a_{S H V}$, which are important for human infections, were found in this study. In contrast, $b l a_{\text {СТХ-м-2 }}$ and $b l a_{\text {СTХ-м-9 }}$ were not detected in any isolate in this study. Among ESBL-producing genes, previous studies found that the most prevalent were $b l a_{\mathrm{SHV}}(7.4 \%)$ and $b l a_{\mathrm{TEM}}(1.8 \%)$ (WAJID et al., $2019 \mathrm{~b})$, bla $_{\mathrm{CTX}-\mathrm{M}-3}$ and $b l a_{\mathrm{CTX}-\mathrm{M}-15}(11.3 \%)$, bla $_{\mathrm{SHV}-12}$ $(7.5 \%)$ and $b l a_{\text {OXA-1 }}(3.7 \%)$ (AHMED et al., 2014). Another study reported that $b l a_{\mathrm{TEM}}(54.17 \%)$, bla $_{\mathrm{SHV}}$

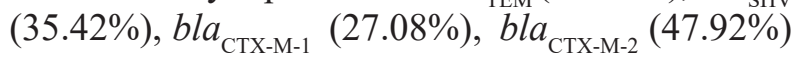
and $b l a_{\text {СТХ-м-9 }}(62.5 \%)$ genes were positive, while $b l a_{\text {CTX-M-8-25 }}$ was negative (REN et al., 2017).

Plasmid-mediated colistin resistance was detected in various Salmonella enterica serovars in previous studies (LIMA et al., 2019). To date, nine different $\mathrm{mcr}$ gene homologues have been identified (CARROLL et al., 2019). In this study, only $m c r-1$ to 5 genes were investigated. Salmonella Typhimurium was found to be the most common serovar bearing mor genes (LIMA et al., 2019). CARFORA et al., (2018) reported that four $S$. Infantis serovars carried the $m c r-1.1$ gene variant. In this study, none of the four isolates with phenotypic colistin resistance were found to carry $\mathrm{mcr}$ genes. These isolates were thought to be one of the other $m c r$ gene variants not investigated in this study.

\section{Conclusion}

It should be remembered that the sources of salmonellosis in the food chain and the ways of transmission are inseparably linked to the risks of infection in humans. In this study, the detected high frequency of the most important zoonotic Salmonella serovar, Infantis, is of public health significance. We revealed that the presence of ESBL-producing Salmonella strains has dramatically increased during the years, especially when compared with chicken meat Salmonella strains previously reported in Turkey. The increase in Salmonella strains, particularly ESBL producers and the colistin resistant, is of great concerns for selected antimicrobial therapy in human infections. Hence, epidemiological information and monitoring systems are extremely important in controlling Salmonella infections in public health services.

\section{Acknowledgment}

This work was supported by the Scientific Research Projects Coordination Unit of Atatürk University (grant numbers TSA2018-6851 and THD-2020-8612). We sincerely thank Ana Rita Rebelo and her team, and also Dr. Cemil Kurekci for supporting the positive bacterial isolates.

\section{References}

ABBASOGLU, D., M. AKCELIK (2011): Phenotypic and genetic characterization of multidrug-resistant Salmonella Infantis strains isolated from broiler chicken meats in Turkey. Biologia. 66, 406-410.

DOI: $10.2478 / \mathrm{s} 11756-011-0051-0$

ABD-ELGHANY, S. M., K. I. SALLAM, A. ABDELKHALEK, T. TAMURA (2015): Occurrence, genetic characterization and antimicrobial resistance of Salmonella isolated from chicken meat and giblets. Epidemiol. Infect. 143, 997-1003.

DOI: $10.1017 / \mathrm{S} 0950268814001708$

ADIGUZEL, M. C., B. DIREN SIGIRCI, B. CELIK, B. BASARAN KAHRAMAN, K. METINER, S. IKIZ, A. F. BAGCIGIL, S. AK, N. Y. OZGUR (2018): Phenotypic and genotypic examination of antimicrobial resistance in thermophilic Campylobacter species isolated from poultry in Turkey. J. Vet. Res. 62, 463-468.

DOI: $10.2478 /$ jvetres-2018-0071

AHMED, A. M., T. SHIMAMOTO, T. SHIMAMOTO (2014): Characterization of integrons and resistance genes in multidrug-resistant Salmonella enterica isolated from meat and dairy products in Egypt. Int. J. Food Microbiol. 189, 39-44.

DOI: 10.1016/j.ijfoodmicro.2014.07.031 
ARRACH, N., S. PORWOLliK, P. CHENG, A. CHO, F. LONG, S. CHOI, M. MCCLELLAND (2008): Salmonella serovar identification using PCR-based detection of gene presence and absence. ¡J. Clin. Microbiol. 46, 2581-2589.

DOI: 10.1128/JCM.02147-07.

ARSLAN, S., A. EYI (2010): Occurrence and antimicrobial resistance profiles of Salmonella species in retail meat products. J. Food Prot. 73, 1613-1617.

DOI: $10.4315 / 0362-028 X-73.9 .1613$

ATA, Z., G. DINC, A. YIBAR, H. K. MUSTAK, O. SAHAN (2015): Extended spectrum $\beta$-lactamase activity and multidrug resistance of Salmonella serovars isolated from chicken carcasses from different regions of Turkey. Ankara Univ. Vet. Fak. Derg. 62, 119-123.

AVSAROGLU, M. D., R. HELMUTH, E. JUNKER, S. HERTWIG, A. SCHROETER, M. AKCELIK, F. BOZOGLU, B. GUERRA (2007): Plasmid-mediated quinolone resistance conferred by qnrS1 in Salmonella enterica serovar Virchow isolated from Turkish food of avian origin. J. Antimicrob. Chemother. 60, 1146-1150.

DOI: $10.1093 / \mathrm{jac} / \mathrm{dkm} 352$

BABACAN, O., H. KARADENIZ (2019): Investigation of antibiotic susceptibility of Salmonella spp. strains' isolated from raw chicken meat. Vet. Hekim. Der. Derg. 90, 105114 (in Turkish).

DOI: $10.33188 /$ vetheder.497569

BARAN, A., A. ERDOGAN, A. KAVAZ, M. C. ADIGUZEL (2019): Some specific microbiological parameters and prevalence of Salmonella spp. in retail chicken meat from Erzurum province, Turkey and characterization of antibiotic resistance of isolates. Biosci. J. 35, 878-891.

DOI: 10.14393/BJ-v35n3a2019-42187

BASARAN KAHRAMAN, B., B. DIREN SIGIRCI, B. CELIK, B. GUMUS, K. METINER, M. C. ADIGUZEL, A. F. BAGCIGIL, S. IKIZ, N. Y. OZGUR, S. AK (2016): Detection of extended-spectrum $\beta$-lactamase and AmpC $\beta$-lactamase producing Escherichia coli isolates from chickens. Kafkas Univ. Vet. Fak. Derg. 22, 591-596.

DOI: $10.9775 / \mathrm{kvfd} .2016 .15121$

BORAH, P., S. PORWOLLIK, P. DESAI, P. NAYAK, P. P. BORAH, P. CHENG, M. MCCLELLAND (2017): A simplified multiplex PCR-based typing method for common Salmonella enterica serovars supported by online server-based detection system. Indian J. Med. Res. 146, 272-280

DOI: 10.4103/ijmr.IJMR_1258_15

BOROWIAK, M., FISCHER, J., HAMMERL, J. A., HENDRIKSEN, R.S., SZABO, I., MALORNY, B (2017): Identification of a novel transposon-associated phosphoethanolamine transferase gene, mcr-5, conferring colistin resistance in d-tartrate fermenting Salmonella enterica subsp. enterica serovar Paratyphi B. J. Antimic. Chem. 72, 3317-3324.

DOI: $10.1093 / \mathrm{jac} / \mathrm{dkx} 327$
BROWN, A. C., J. C. CHEN, L. K. F. WATKINS, D. CAMPBELL, J. P. FOLSTER, H. TATE, J. WASILENKO, C. VAN TUBBERGEN, C. R. FRIEDMAN (2018): CTX-M-65 extended-spectrum b-lactamase-producing Salmonella enterica serotype Infantis, United States. Emerg. Infect. Dis. 24, 2284-229.

DOI: $10.3201 /$ eid2412.180500

CARFORA, V., P. ALBA, P. LEEKITCHAROENPHON, D. BALLARÒ, G. CORDARO, P. D. MATTEO, V. DONATI, A. IANZANO, M. IURESCIA, F. STRAVINO, T. TAGLIAFERRI, A. BATTISTI, A. FRANCO (2018): Colistin resistance mediated by $m c r-1$ in ESBL-producing, multidrug resistant Salmonella Infantis in broiler chicken industry, Italy (2016-2017). Front. Microbiol. 17, 1880.

DOI: $10.3389 /$ fmicb.2018.01880

CARROLL, L. M., A. GABALLA, C. GULDIMANN, G. SULLIVAN, L. O. HENDERSON, M. WIEDMANN (2019): Identification of novel mobilized colistin resistance gene $m c r-9$ in a multidrug-resistant, colistin-susceptible Salmonella enterica serotype Typhimurium isolate. mBio. 10, e00853-19.

DOI: $10.1128 / \mathrm{mBio} .00853-19$

CLSI (2017): Performance standards for antibacterial susceptibility testing. $27^{\text {th }}$ ed. Clinical and Laboratory Standards Institute M100-s23.

EFSA and ECDC (European Food Safety Authority and European Centre for Disease Prevention and Control) (2018): The European union summary report on trends and sources of zoonoses, zoonotic agents and food-borne outbreaks in 2017. EFSA Journal. 16, 262.

DOI: $10.2903 /$ j.efsa.2018.5500

EUCAST (2017): Media preparation for EUCAST disk diffusion testing and for determination of MIC values by the broth microdilution method. European Committee on Antimicrobial Susceptibility Testing, pp. 1-5.

EUCAST (2019): Breakpoint tables for interpretation of MICs and zone diameters. European Committee on Antimicrobial Susceptibility Testing, pp. 10-15.

KIRKAN, S., S. SAVASAN, U. PARIN, H. T. YÜKSEL (2017): Multiple antibotic resistance and risk management in poultry breeding. Turkiye Klinikleri J. Vet. Sci. Pharmacol. Toxicol. - Special Topics. 3, 264-268 (in Turkish).

LE, Q. P., S. UEDA, T. N. NGUYEN, T. V. DAO, T. A. VAN HOANG, T. T. TRAN, I. HIRAI, T. NAKAYAMA, R. KAWAHARA, T. H. DO, Q. M. VIEN, Y. YAMAMOTO (2015): Characteristics of extended-spectrum $\beta$-Lactamaseproducing Escherichia coli in retail meats and shrimp at a local market in Vietnam. Foodborne Pathog. Dis. 12, 719725 .

DOI: $10.1089 /$ fpd.2015.1954

LEADER, B. T., J. G. FRYE, J. HU, P. J. FEDORKACRAY, D. S. BOYLE (2009): High-throughput molecular determination of Salmonella enterica serovars by use of 
multiplex PCR and capillary electrophoresis analysis. J. Clin. Microbiol. 47, 1290-1299.

DOI: 10.1128/JCM.02095-08

LEVY, H., S. DIALLO, S. M. TENNANT, S. LIVIO, S. O. SOW, M. TAPIA, P. I. FIELDS, M. MIKOLEIT, B. TAMBOURA, K. L. KOTLOFF, R. LAGOS, J. P. NATARO, J. E. GALEN, M. M. LEVINE (2008): PCR method to identify Salmonella enterica serovars Typhi, Paratyphi A, and Paratyphi B among Salmonella isolates from the blood of patients with clinical enteric fever. J. Clin. Microbiol. 46, 1861-1866.

DOI: $10.1128 /$ JCM.00109-08

LI, S., Y. ZHOU, Z. MIAO (2017): Prevalence and antibiotic resistance of non-typhoidal Salmonella isolated from raw chicken carcasses of commercial broilers and spent hens in Tai'an, China. Front. Microbiol. 8, 2106.

DOI: $10.3389 /$ fmicb.2017.02106

LIMA, T., S. DOMINGUES, G. J. DA SILVA (2019): Plasmidmediated colistin resistance in Salmonella enterica: A review. Microorganisms. 7, 55.

DOI: 10.3390/microorganisms7020055.

LYNCH, J. P., N. M. CLARK, G. G. ZHANEL(2013): Evolution of antimicrobial resistance among Enterobacteriaceae (focus on extended spectrum $\beta$-lactamases and carbapenemases). Expert Opin. Pharmacother, 14, 199-210.

DOI: $10.1517 / 14656566.2013 .763030$

MOURA, Q., M.R. FERNANDES, K. C. SILVA, D. F. MONTE, F. ESPOSITO, M. DROPA, C. NORONHA, A. M. MORENO, M. LANDGRAF, F. J. NEGRÃO, N. LINCOPAN (2018): Virulent nontyphoidal Salmonella producing CTXM and CMY-2 b-lactamases from livestock, food and human infection, Brazil. Virulence. 9, 281-286.

DOI: 10.1080/21505594.2017.1279779

NGUYEN, D. T., M. KANKI, P. D. NGUYEN, H. T. LE, P. T. NGO, D. N. TRAN, N. H. LE, C. V. DANG, T. KAWAI, R. KAWAHARA, S. YONOGI, Y. HIRAI, M. JINNAI, S. YAMASAKI, Y. KUMEDA, Y. YAMAMOTO (2016): Prevalence, antibiotic resistance, and extended-spectrum and AmpC $\beta$-lactamase productivity of Salmonella isolates from raw meat and seafood samples in Ho Chi Minh City, Vietnam. Int. J. Food. Microbiol. 7, 115-122.

DOI: $10.1016 /$ j.ijfoodmicro.2016.07.017

NIDAULLAH, H., A. K. MOHD OMAR, A. ROSMA, N. HIDA, S. SOHNI (2016): Analysis of Salmonella contamination in poultry meat at various retailing, different storage temperatures and carcass cuts - A literature survey. Int. J. Poult. Sci. 15, 111-120.

DOI: $10.3923 /$ ijps.2016.111.120

NÓGRÁDY, N., M. KIRÁLY, R. DAVIES, B. NAGY (2012): Multidrug resistant clones of Salmonella Infantis of broiler origin in Europe. Int. J. Food Microbiol. 157, 108-112.

DOI: 10.1016/j.ijfoodmicro.2012.04.007
QIAO, J., W. Q. ALALI, J. LIU, Y. WANG, S. CHEN, S. CUI, B. YANG (2018): Prevalence of virulence genes in extended-spectrum b-lactamases (ESBLs)-producing Salmonella in retail raw chicken in China. J. Food Sci. 83, 1048-1052.

DOI: $10.1111 / 1750-3841.14111$

REBELO, A. R., V. BORTOLAIA, J. S. KJELDGAARD, S. K. PEDERSEN, P. LEEKITCHAROENPHON, I. M. HANSEN, B. GUERRA, B. MALORNY, M. BOROWIAK, J. A. HAMMERL, A. BATTISTI, A. FRANCO, P. ALBA, A. PERRIN-GUYOMARD, S. A. GRANIER, C. DE FRUTOS ESCOBAR, S. MALHOTRA-KUMAR, L. VILLA, A. CARATTOLI, R. S. HENDRIKSEN (2018): Multiplex PCR for detection of plasmid-mediated colistin resistance determinants, $m c r-1, m c r-2, m c r-3, m c r-4$ and $m c r-5$ for surveillance purposes. Euro Surveill. 23, 1-17.

DOI: 10.2807/1560-7917.ES.2018.23.6.17-00672

REN, D., P. CHEN, Y. WANG, J. WANG, H. LIU, H. LIU (2017): Phenotypes and antimicrobial resistance genes in Salmonella isolated from retail chicken and pork in Changchun, China. J. Food Saf. 37, e12314.

DOI: $10.1111 /$ jfs. 12314

RODRÍGUEZ, I., W. BAROWNICK, R. HELMUTH, M. C. MENDOZA, M. R. RODICIO, A. SCHROETER, B. GUERRA (2009): Extended-spectrum $\beta$-lactamases and AmpC $\beta$-lactamases in ceftiofur-resistant Salmonella enterica isolates from food and livestock obtained in Germany during 2003-07. J. Antimicrob. Chemother. 64, 301-309.

DOI: $10.1093 / \mathrm{jac} / \mathrm{dkp} 195$

SAHAN, O., E. M. ARAL, M. M. A. ADEN, A. AKSOY, O. YILMAZ, R. JAHED, M. AKAN (2016): Distribution and antibiotic resistance of Salmonella isolates from broiler enterprices in Turkey. Ankara Univ. Vet. Fak. Derg. 63, 1-6 (in Turkish).

VAN DUIJKEREN, E., W. J. WANNET, D. J. HOUWERS, W. VAN PELT (2003): Antimicrobial susceptibilities of Salmonella strains isolated from humans, cattle, pigs, and chickens in the Netherlands from 1984 to 2001. J. Clin. Microbiol. 41, 3574-3578.

DOI: $10.1128 / J C M .41 .8 .3574-3578.2003$

WAJID, M., A. B. AWAN, M. K. SALEEMI, J. WEINREICH, P. SCHIERACK, Y. SARWAR, A. ALI (2019a): Multiple drug resistance and virulence profiling of Salmonella enterica serovars Typhimurium and Enteritidis from poultry farms of Faisalabad, Pakistan. Microb. Drug. Resist. 25, 133-142.

DOI: $10.1089 / \mathrm{mdr} .2018 .0121$

WAJID, M., M. K. SALEEMI, Y. SARWAR, A. ALI (2019b): Detection and characterization of multidrug-resistant Salmonella enterica serovar Infantis as an emerging 
threat in poultry farms of Faisalabad, Pakistan. J. Appl. Microbiol. 127, 248-261.

DOI: $10.1111 /$ jam. 14282

XAVIER, B. B., C. LAMMENS, R. RUHAL, S. KUMARSINGH, P. BUTAYE, H. GOOSSENS, S. MALHOTRAKUMAR (2016): Identification of a novel plasmidmediated colistin-resistance gene, mcr-2, in Escherichia coli, Belgium, June 2016. Euro Surveill. 21, 30280.

DOI: 10.2807/1560-7917.es.2016.21.27.30280

YANG, B., D. QU, X. ZHANG, J. SHEN, S. CUI, Y. SHI, M. XI, M. SHENG, S. ZHI, AND J. MENG (2010): Prevalence and characterization of Salmonella serovars in retail meats of marketplace in Shaanxi, China. Int. J. Food Microbiol. 141, 63-72.

DOI: $10.1016 /$ j.ijfoodmicro.2010.04.015

ZWE, Y. H., V. C. Y. TANG, K. T. AUNG, R. A. GUTIÉRREZ, L. C. NG, H. G. YUK (2018): Prevalence, sequence types, antibiotic resistance and, gyrA mutations of Salmonella isolated from retail fresh chicken meat in Singapore. Food Control. 90, 233-240.

DOI: 10.1016/j.foodcont.2018.03.004

\begin{abstract}
ADIGUZEL, M. C., S. CENGIZ, A. BARAN: Molekularna serotipizacija sojeva bakterije Salmonella izoliranih iz pilećeg mesa za prodaju, na temelju in silico višestrukog PCR-a, određivanja ESBL-a i gena kolistin rezistencije $m c r-1$ do $\mathbf{- 5}$. Vet. arhiv 91, 179-187, 2021.
\end{abstract}

\title{
SAŽETAK
}

Salmonella spp. zoonotski su patogeni koji uzrokuju infekcije u ljudi i životinja. Na globalnoj su razini najčešći patogeni koji se prenose hranom poslije bakterija Campylobacter spp. Cilj ovog istraživanja bio je fenotipski i genotipski odrediti $\beta$-laktamaze proširenog spektra (ESBL) i otpornost na kolistin 67 sojeva bakterija Salmonella spp. izoliranih iz pilećeg mesa za prodaju od svibnja do prosinca 2016. i pohranjenih u kulturama na Odsjeku za mikrobiologiju Fakulteta veterinarske medicine na Sveučilištu Ataturk. Izolati su serotipizirani primjenom višestruke lančane reakcije polimerazom (mPCR). Distribucija serovara bila je: $74,6 \%$ za $S$. Infantis, $16,4 \%$ za $S$. Enteritidis, $3,0 \%$ za $S$. Arizonae, $3,0 \%$ za $S$. Dublin, $1,5 \%$ za $S$. Gallinarum i 1,5 \% za $S$. Indica. Od 67 sojeva njih je 20 (29,9 \%) bilo pozitivno na ESBL. Glavni identificirani tipovi $\beta$-laktamaza bili su: $b l a_{\mathrm{CTX}-\mathrm{M}-1}, b l a_{\mathrm{CTX-M-8-25}}, b l a_{\mathrm{SHV}} \mathrm{i} b l a_{\mathrm{TEM}}$. Četiri izolata bila su fenotipski otporna na kolistin. Ovi izolati nisu sadržavali aktivne gene rezistencije na kolistin (mcr) 1 do 5. U ovom su istraživanju nađeni i sojevi salmonele koji su genotipski proizvodili ESBL i sojevi fenotipski otporni na kolistin. Sojevi salmonele koji proizvode ESBL s godinama su se znatno povećali, posebno u usporedbi s prethodnim izvješćima o sojevima salmonele u mesu pilića u Turskoj. Porast sojeva salmonele, osobito onih koji proizvode ESBL i onih koji su otporni na kolistin, zabrinjava zbog antimikrobnog liječenja infekcija u ljudi. Zbog toga su u kontroli infekcija salmonelama u javnome zdravstvu iznimno važni epidemiološki podaci i sustavi praćenja.

Ključne riječi: kolistin; ESBL; pileće meso za prodaju; Salmonella spp.; serotipizacija 
